Eskişehir Osmangazi Üniversitesi

Sosyal Bilimler Dergisi

Haziran 2020, 21(1), 99-115

DOI: 10.17494/ogusbd.763414

\title{
Seçimlerde Komşusundan Ayrıksılaşan ilç̧eler ve Ayrıksılaşmayı Sağlayan Dinamikler
}

\author{
Suat TUYSUZ, Recep GÜLMEZ, Kader MUTLU*
}

Seçimlerde Komşusundan Ayrıksılaşan İlçeler ve
Ayrıksılaşmayı Sağlayan Dinamikler

Özet

$\mathrm{Bu}$ araştırma birbiriyle ilişkili üç amacı gerçekleştirmeyi hedeflemektedir. Illk amaç, ilçe ölçeğinde komşularıyla benzer özellik gösteren ilçelerin istatistiksel olarak anlamlı bir biçimde kümelendikleri bölgeleri ortaya çıkarmaktır. İkincisi ve daha da önemlisi söz konusu anlamlı kümelenmelerin olduğu bölgelere komşu olup ancak komşularından farklı düşünen ayrıksı ilçeleri ortaya çıkarmaktır. Sonuncusu ise ayrıksı ilçelerin komşularıyla farklılaşma nedenlerinin demografik, kültürel ve ekonomik dinamiklerle herhangi bir ilişki içinde olup olmadığını anlamaya yöneliktir. Bir başka ifadeyle ayrıksılaşmayı yaratan dinamiği ortaya çıkarmaktır. İlk ve ikinci amacı gerçekleştirebilmek için partilerin oy oranları hesaplanmış ve elde edilen oransal veri Anselin Lokal Moran's I (LISA) analizine alınmıştır. Bu analizle ilk ve ikinci amaca yönelik olacak şekilde hem sınır komşuluğuna göre anlamlı olarak kümelenen hem de komşusundan ayrışan ilçeler tespit edilmiştir. Ardından yapılan Mann-Whitney $U$ testiyle ise tespit edilen ayrıksı ilçelerin demografik, kültürel ve ekonomik dinamikler açısından komşularından farklılaşıp farklılaşmadığı ortaya konulmuştur. Bulgular, ayrıksı ilçelerin komşularından anlamlı bir biçimde farklılaştığını, yalnızca eğitim durumunun ayrıksılaşmayı yaratan dinamik olduğunu göstermektedir.

Anahtar kelimeler: Seçimler, komşuluk etkisi, kümelenme, Anselin Lokal Moran's I

Makale Türü: Araştırma

\section{Giriş}

Anomalous Districts in Elections and Their Dynamics Promoting Anomality

\section{Abstract}

This research aims to achieve three interrelated goals. The first aim is to reveal the regions where the districts which have similar characteristics with their neighbors are clustered in a statistically significant way. Secondly, and more importantly, it is to reveal anomalous districts that are neighboring regions with such significant clusters but which are distinguished from their neighbors. Finally, it is aimed to examine whether the reasons of differentiation of anomalous districts with their neighbors are in any relation with demographic, cultural and economic dynamics. In other words, it is to reveal the dynamics that create anomality. In order to achieve the first and second aim, the voting rates of the parties were calculated and the proportional data obtained were analyzed by the Anselin Local Moran I (LISA). With this analysis, districts that are both clustered according to their neighborhood and separated from their neighbors are determined in accordance with the first and second goals of the research. The Mann-Whitney $U$ test revealed whether the different districts identified are distinguished from their neighbors in terms of demographic, cultural and economic dynamics. The findings show that anomalous districts differ significantly from their neighbors and only the educational situation is a dynamic, which creates differentiation.

Keywords: Elections, neighborhood effect, cluster, Anselin Local Moran's I

Paper Type: Research

*Suat TUYSUZ, Dr. Öğr. Üyesi, Erzincan Binali Yıldırım Üniversitesi, FEF Coğrafya Bölümü, suattuysuz@gmail.com, ORCID
ID orcid.org / 0000-0002-6598-0746 Recep GÜLMEZ, Dr. Öğr. Üyesi, Erzincan Binali Yıldırım Üniversitesi, iiBF Siyaset
Bilimi ve Kamu Yönetimi Bölümü, rgulmez@erzincan.edu.tr, ORCID ID orcid.org / 0000-0002-5073-5051, Kader MUTLU,
Yüksek Lisans Öğrencisi, Erzincan Binali Yıldırım Üniversitesi, Sosyal Bilimler Enstitüsü Coğrafya ABD
kadermtI24@gmail.com, ORCID ID orcid.org / 0000-0003-4711-3048

Makale Gönderim Tarihi 26/03/2020

Makale Kabul Tarihi 17/06/2020 
Dünyada demokratik seçimlerin yapıldığı hemen her ülkede görülen siyasi rekabet ve siyasi kutuplaşmalar beraberinde mekânsal kutuplaşmaları da getirmektedir. Öyle ki 2000 yılındaki ABD seçimlerinde medya tarafından cumhuriyetçilerin kazandığı bölgeler için kırmızı eyaletler, demokratların kazandığı bölgeler için ise mavi eyaletler şeklindeki bir tanımlama yalnızca Amerikan toplumundaki muhafazakar ve liberallerin haritalandırımasını değil aynı zamanda bir kültür bölgesinin mekânsallığını da ifade etmektedir (Domosh vd., 2010). Bahsi geçen haritaya bakıldığında kırmızı ve mavi renklerin birbirine karışmayacak biçimde homojen bir mekânsal örüntü yarattığı dikkat çekmektedir (Domosh vd., 2010: 187). Böylesi bir mekânsal örüntünün belirginleştiği ülkelerden biri de kuşkusuz Türkiye'dir. Türkiye'nin dinamik olan toplumsal yapısı esas alındığında bu örüntünün dönemsel olarak farklı tanımlandığı belirtilebilir. Bu çerçevede Türkiye'deki siyasi desen ve onun bir sonucu olarak oluşan mekânsal desen Özözen-Kahraman ve Gültay'ın (2019: 9596) ifadeleriyle söylenecek olursa cumhuriyetin ilk yıllarında merkez-çevre, 1950'lerden sonra sağsol, 1980'lerden sonra küresel-ulusal [liberal-muhafazakar], 1990'ların ortalarından itibaren dindarlaik, 2000'lerden sonra ise vatandaşlık-kimlik ekseninde şekillenen dinamik bir yapı göstermektedir.

Yukarıda anlatılanlar bağlamında Türkiye'de seçimler ve onun mekânsal boyutuna ilişkin yapılan çalışmalarda dikkat çeken husus daha çok partilerin veya siyasi görüşlerin/ideolojilerin kemikleştiği bölgelerin tespitine yönelik araştırmalar ve siyasi partiler ile seçmen profili arasındaki ilişkiyi ele alan çalışmalar şeklinde kendini göstermektedir. Bu bağlamda siyasi görüşlerin yerleşik hale geldiği bölgeleri tespit eden önemli çalışmalardan biri Işık ve Pınarcıoğlu (2006) tarafından yapılandır. Söz konusu araştırmada siyasi görüşlerin; merkez sol, merkez sağ, milliyetçi sağ, İslamcı sağ ve bölgesel sol şeklinde sınıflandıııldı̆ı, ideolojilerin birbiriyle komşuluk ilişkilerinin değerlendirildiği ve hangi bölgelerde hangi siyasi eğilimlerin yerleşik ideoloji haline geldiği tespit edilmektedir. Buradan hareketle bahsi geçen araştırma yenice kurulmuş bir oluşum olarak Adalet ve Kalkınma Partisi'nin (AKP) hangi ideolojilerin kemikleştiği bölgelerden oy aldığına veya hangi ideolojilerin yerleşik olduğu bölgelerde kendine zemin bulamadığına odaklanmaktadır. Benzer şekilde Kaya, Toroğlu, ve Adıgüzel (2015) tarafından yapılan bir çalışmada da ilçe ölçeğinde siyasi partilerin aldığı oy miktarına göre nerelerde anlamlı kümelenmeler gerçekleştirdiği tespit edilerek siyasi partilerin etki sahaları haritalanmıştır. Farklı yöntemler kullanılsa da hem ışık ve Pınarcıoğlu (2006) hem de Kaya ve ark. (2015) tarafından yapılan çalışmalardaki analizler belli siyasal ideolojilerin kümelendikleri bölgeleri ortaya çıkarmaya yönelik çalışmalar olarak dikkatleri çekmektedir. ÖzözenKahraman'ın (2007) çalışması ise siyasi partilerin bir bölgeden aldığı oy miktarı ile seçmen profili arasındaki ilişkiyi ortaya koyan türdendir.

Türkiye'deki seçim ve seçmenlerle ilgili yapılan bahsi geçen çalışmalar mekana yaptıkları vurguyla dikkat çeker. Öyle ki bu durum sosyal bilimlerin çeşitli alanlarında mekânsal dönüş şeklinde kavramsallaştırımaktadır. Bu çerçevede mekânın siyaset, toplum ve iktisadi faaliyetlerdeki rolünü anlamaya yönelik eğilimlerde artış yaşandığı belirtilebilir. Bu durum yeni kavram setlerinin ve analiz yöntemlerinin gelişmesine de zemin hazırlamıştır. Bu minvalde geliştirilen kavramlardan biri de mekânsal bağımlıık kavramıdır. Mekansal bağımlıık olarak adlandırılan kavramın dayanak noktası, mekanda birbirine yakın olan olguların birbiriyle daha çok etkileşim içinde olmasını ifade etmektedir. 
Bu da coğrafyada Tobler'in birinci yasası olarak bilinen 'her şey birbiriyle ilişki içindedir, ama mekânsal olarak birbirine yakın olan olay ve süreçler birbirini daha çok etkiler' şeklindeki önermesine dayalıdır (Işı ve Pınarcıoğlu, 2006). Bu bağlamda vurgulandığı üzere gerek Işık ve Pınarcıoğlu (2006) gerekse de Kaya ve ark. (2015) tarafından yapılan çalışmalar mekânsal bağımlıı̆ı ve kümelenmeleri analiz eden bir yaklaşıma sahiptir. Bahsi geçen çalışmalardan ilki 1990'lar ve 2002' deki seçimleri ele almakta, ikincisi ise 2011 yılındaki seçimlere odaklanmaktadır. Benzer şekilde Gündem (2017) de seçimlerde mekânsal etkiyi analiz eden bir yaklaşımla çalışmasını yürütmüştür. Özözen-Kahraman ve Gültay'ın (2019) çalışması ise 2007 ve 2015 seçim sonuçlarına göre ilçelerin oy rengini tespit ederek ortalamadan belirgin bir biçimde sapmış olanların sıradışı ilçe olarak tanımlanmasına yöneliktir. Ancak belirtmek gerekir ki burada sıradışı olarak tanımlanma durumu ilçelerin Türkiye genelindeki ortalamalardan farklılaşmasına göre belirlenmektedir.

Bu noktada bu araştırmada her ne kadar farklı seçim dönemindeki veriler kullanılmış olsa da yukarıda bahsedilen çalışmalarla benzeşen ve ayrışan taraflarının olduğunu vurgulamak gerekir. Farklı seçim verisi kullanılmış olsa da partilerin anlamlı olarak kümelendikleri bölgelerin tespitinde yöntemsel açıdan bir benzerlik söz konusudur. Ancak bu çalışma ayrıksı ilçelerin tespiti noktasında literatürdeki diğer çalışmalardan farklılaşmaktadır. Bu çerçevede örneğin Özözen-Kahraman ve Gültay'ın (2019) çalışmasında sıradan ilçelerin tespiti Türkiye ortalamaları esas alınarak gerçekleştirilmişken bizim çalışmamızda bu durum tamamen komşuluk ilişkisine dayalı olarak gerçekleştirilmiştir. Buradan hareketle komşusundan farklılaşan ilçeler ayrıksı ilçeler olarak tanımlanmıştır ki bu da çalışmanın diğer çalışmalardan ayrılan yönüne işaret etmektedir. Ayrıca, ayrıksı ilçelerin komşularından farklılaşmasının ardında herhangi bir düzenlilik ya da düzensizlik olup olmadığını anlamaya yönelik bir çerçeveye sahip olması da bu çalışmayı diğerlerinden ayırmaktadır.

Çalışma komşuluk etkisini dikkate alarak bir seçim bölgesinin sınır komşusundan farklılaşmasını Anselin Lokal Moran I (LISA) testiyle; farklılaşan ilçelerin komşularından ayrışma nedenini ise ManWhitney U testiyle analiz etmektedir. Bu yönüyle Özözen-Kahraman ve Gültay (2019), Gündem (2017), Kaya ve diğerleri (2015), Işık ve Pınarcıoğlu’nın (2006) çalışmalarından farklılaşmaktadır. Bu çerçevede ayrıksı ilçelerin belirlenmesinde belli bir düzen ya da düzensizliğin ortaya konulması gibi bir hedef; demografik, kültürel ve ekonomik olarak sınıflandırılan değişkenler üzerinden gerçekleştirilmeye çalışılmıştır.

\section{Teorik Arka Plan}

Komşuluk etkisi olarak tanımlanabilecek olan mekansal yasa, Tobler'in (1970: 236) coğrafyanın birinci kuralı olarak ifade ettiği 'her şey her şeyle ilgilidir, fakat yakındakiler uzaktakilerden daha fazla ilişkilidir', mantığına dayanmaktadır. Komşuluk etkisini ele alan çalışmaların tarihi oldukça eskilere gitmektedir. Bu konuda Cox'un (1969a, 1969b, 1969c) farklı kentlerde yaptığı araştırmalar öncü çalışmalar olarak kabul edilebilir. Komşuluk etkisi olarak kavramsallaştırılan bu durum, mekansal yakınlığı esas almak kaydıyla bireylerin birbirinden etkilendiğini ifade eden bir çerçeveye sahiptir (Işık ve Pınarcıoğlu, 2006). Söz konusu çerçeve birbirine mekansal olarak yakın olan bireylerin veya toplumların birbirinden etkilenerek kararlarını şekillendirdiğini belirtmektedir (Bølstad ve Dinas, 
2017; Pattie ve Johnston, 1999, 2000). Buradan hareketle birbirine yakın bölgelerde yaşayan bireylerin/seçmenlerin birbirleri üzerinde homojenleştirici bir etkide bulunarak birbirlerine benzemeye başladıkları görülmektedir. Özellikle yakın çevre ve akrabaların oy verme davranışları birbirlerine fiziksel yakınlıklarından dolayı etkilenmektedir (Ochoa-Espejo, 2016). Gerçekten de coğrafi yakınlığın seçmenlerin siyasal davranışlarını şekillendiren unsurlardan biri olduğu vurgulanmaktadır (Deutschmann vd., 2018). Dolayısıyla fiziksel yakınlık, siyasal karar mekanizmalarında önemli bir dinamik olarak belirmektedir.

Seçmen davranışı açısından bakıldığında Johnston ve diğerleri (2004), Walks (2005), Walks'un (2006) yaptığı analizler benzer niteliklere sahip kişilerin farklı mekanlarda farklı bir davranış kalıbı geliştirdiğini ortaya koymaktadır. Benzer niteliklere sahip seçmenlerin farklı mekanlarda farklı davranış biçimi geliştirmeleri ne ilişkin örnekler komşuluk etkisi olarak tanımlanan çerçeveyle açıklanabilmektedir. Mikesova (2019: 431) tarafından yapılan bir araştırma bu davranış kalıbının seçimlere katılım noktasında olabildiği gibi parti tercihleri noktasında da farklılaşabileceğini göstermektedir. Dolayısıyla hem seçimlere katılım durumunun hem de parti tercihlerinin yerel bağlamdan etkilenen bir yapıda olduğu ortaya konulmuştır. Bir diğer ifadeyle seçimlerin yapıldığı yerel ortamın seçmen davranışını doğrudan etkilediğine ilişkin çalışmalar mekana yaptıkları vurguyla dikkatleri çekmektedir. Özü değiştiren bu durum, Işık ve Pınarcıoğlu'nun (2006) ifadesiyle mekansal bağımlıık olarak tanımlanmaktadır. Mekanda cereyan eden bu dönüşüm, mekanın dönüştürücü etkisi olarak da kavramsallaştırılabilir. Mekansal yakınlıktan kaynaklanarak gerçekleşen böylesi bir homojenliğin üst ölçekten bakıldığında mekansal kutuplaşmalara da dayanak oluşturduğu görülmektedir (Johnston vd., 2004). Bir başka ifadeyle birbirinden etkilenerek benzer davranış örüntüsü geliştiren toplumların homojenleştirici bölgeler oluşturması mekansal açıdan birbirine benzeyen ve ayrışan bölgelerin oluşumuna da zemin hazırlamaktadır (Walks, 2005, 2006).

Benzer yapıdaki bireylerin farklı mekanlarda farklı bir davranış örüntüsü geliştirdiğine ilişkin yapılan vurgular her ne kadar komşuluk etkisinin varlığına işaret etse de kuşkusuz seçmen davranışı yalnızca bu türden bir mekansal fetişizme de indirgenemez. Mekansal bir fetişizmden uzaklaşıldı̆̆ında çok farklı dinamiklerin de seçmen davranışını şekillendirdiği görülmektedir. Örneğin, seçmenlerin gelir durumunun seçmen davranışını şekillendirebilecek bir özellik olabileceği dikkat ortaya konulmuştur. Bu çerçevede yüksek işsizlik oranlarının olduğu veya muhalif partinin seçmen kitlesinin yoğunlaştığı bölgelerde seçmenlerin seçime katılmama gibi bir davranış örüntüsü geliştirdikleri ifade edilmektedir (Del Monte vd., 2019). Yukarıda anlatılanlarla paralel olarak mekanın dönüştürücü etkisine tekrar dönüldüğünde burada ölçek hususunun da dönüştürücü bir unsur olarak devreye girdiği dikkatleri çekmektedir. Bu minvalde özellikle ilçe ya da belde gibi küçük ölçekli seçim bölgelerinde yerel faktörlerin seçmen davranışını etkilediği belirtilmektedir. Coğrafi kutuplaşmaya da dayanak oluşturan bu durumun partizan kutuplaşmasına dönüşebildiği vurgulanmaktadır (Kinsella vd., 2015). Bireyin işyeri, mahallesi, ait olduğu dini grup, üyesi olduğu dernek veya arkadaş çevresi gibi belli bir topluluğa aidiyetini gösteren hususlar da seçim davranışını şekillendirebilmektedir (Anderson, 2009). Nitekim, Almond ve Verba (2015) Amerika'da seçim davranışı ve siyasi kültürün sosyal çevreden etkilendiğini belirtmektedir. 
Öte yandan demografik özelliklerin de seçmen davranışını şekillendirebileceği belirtilmektedir. Örneğin, Almanya gibi yaşlı nüfusa sahip olan ülkelerde kimi partilerin gençlere ve yaşlılara yönelik olmak üzere ayrışmaları, partilerin oy depolarının yaş gruplarına göre farklılaştığını göstermesi açısından çarpıcıdır. Özellikle yaşlı haklarına yönelen siyasi partilerin doğal olarak bu grupların oyunu aldığı ortaya konulmaktadır. Öyle ki demografik özelliklere göre şekillenebilen bu durum emeklilik demokrasisi (pensioner democracy) şeklinde kavramsallaştırılmaktadır (Bergmann vd., 2012: 374). Böyle bir gösterge, yaş faktörünün parti tercihinde rol oynayan bir faktör olabileceğini göstermektedir.

Siyaset psikolojisi açısından bakıldığında da bireylerin kendilerini daha rahat hissettikleri kişilerle iç grup oluşturma eğilimi gösterdiği ortaya konulmuştur. Bu bağlamda, Cottam ve diğerlerine göre (2004: 68) bireyler; tutumlar, inançlar, sosyo-ekonomik statü ve fiziksel görünüş açısından kendilerine benzer olanlarla iç grup olarak birlikte zaman geçirme isteği duyarlar. Festinger ve diğerlerinin (1963: 33) bu konuda yaptığı vurgu ise bireylerin mekânsal olarakyakındaki kişilerle daha fazla ilişki kurma eğiliminde olmasına yöneliktir. Öyle ki komşu, sınıf arkadaşı veya iş arkadaşı olanlar daha fazla etkileşim kurarlar. Bireyler arası çekim açısından benzer ideolojiyi, siyasal ideolojiyi paylaşan, aynı dili konuşan, aynı etnik kökenden gelenler birbirleriyle daha fazla yakınlaşma göstermektedirler. Kuşkusuz bu durumun doğal bir sonucu olarak mekânsal bir kümelenme de baş gösterir. Bu husus mekânsal olarak etkileşim sahası içindeki toplulukların birbirinden etkilendiğini göstermesi açısından dikkate değerdir. Komşuluk etkisi olarak kavramsallaştırılan bu durum, söz konusu etkiden ötürü bir partinin aldığı oyun bir bölgede daha fazla kümelenmesine yol açmaktadır (Johnston, 1986: 41). Bu durum özellikle bir bölgedeki hakim parti lehine daha fazla gerçekleşmektedir. Gerçekten de belli bir partinin oy oranının yüksek olduğu bölgeler aksi yönde düşünen siyasal eğilime sahip seçmenlerin kararlarını da hakim parti lehine olacak şekilde dönüştürebilmektedir. Zira bu durum daha önceki satırlarda da vurgulandığı üzere komşuluk etkisinin işlerliğini göstermektedir.

Öz itibariyle yereldeki dinamikler seçmenlerin parti tercihlerinin anlaşılmasında önemli rol oynar (Johnson vd., 2002: 222). Belirtmek gerekir ki ne cinsiyet ve mesleki statü gibi nedenler ne de yaş, eğitim durumu veya komşuluk etkisi gibi faktörler tek başına seçmenlerin siyasal parti tercihlerinin şekillenmesinde rol oynamazlar. Ancak şunu da vurgulamak gerekir ki bulunulan yer veya komşuluk, seçmenlerin siyasal tercihlerin arkasında yatan dinamikleri anlamada dikkate alınması gereken önemli bir faktör olarak belirmektedir. Öyle ki seçmenler komşularının siyasal davranışından belirgin bir biçimde etkilenmektedirler (Flint, 1996: 148).

\section{Veri}

Çalışmanın yukarıda belirtilen amacını gerçekleştirebilmek için TÜiK'ten ve SGK'dan alınan ilçe düzeyindeki veriler kullanılmıştır. Elde edilen verilerin hepsi ilçedeki seçmen çağındaki nüfusa oranlanarak analizlere alınmıştır. İlçe ölçeğinde verinin bulunabilirliği çerçevesinde kültürel yapıyı ölçmek için nüfusun eğitim durumu; demografik yapının ölçümü için nüfusun yaş yapısı; ekonomik durumu ölçmek için ise istihdamı işaret eden sigortalı sayıları esas alınmıştır (Tablo 1). 
Verilerin detayına bakıldığında eğitim durumu aşağıdaki şekilde dört kategoriye ayrılarak analizlere alınmıştır. Bunlar: a) okuma yazma bilmeyen ve bir okul bitirmeyenlerin oranı, b) ilköğretim mezunu nüfusun oranı, c) ortaöğretim mezunu nüfusun oranı, d) üniversite mezunu nüfusunun oranı şeklindedir. Yaş grupları da aşağıdaki gibi dört kategoriye ayrımıştır. Bunlar: a) 2034 yaş grubu, b) 35-49 yaş grubu, c)50-64 yaş grubu, d) 65 ve üzeri şeklindedir. İ̧̧ücüne katılım durumunu göstermesi açısından kullanılan sigortalı sayıları ise SSK, Bağkur ve Emekli Sandığı'na kayıtlı kişilerin toplamını kapsamaktadır.

Tablo 1: Araştırmada Kullanılan Veriler, Verilerin Tanımlanması ve Veriye Uygulanan Analiz

\begin{tabular}{lccc}
\hline \hline Veri & Ölçek & Uygulanan analiz & Veri kaynağı \\
\hline Partilerin aldıkları oy oranı & İçe & $\begin{array}{c}\text { Anselin Lokal } \\
\text { Moran's I }\end{array}$ & TÜik \\
\hline $\begin{array}{l}\text { Seçmen nüfusun eğitim durumuna } \\
\text { göre oranı }\end{array}$ & ilç̧e & & TÜiK \\
$\begin{array}{l}\text { Seçmen nüfusun yaş gruplarına } \\
\text { göre oranı }\end{array}$ & illçe & Mann-Whitney U & TÜiK \\
$\begin{array}{l}\text { Sigortalı sayılarının nüfusa oranı } \\
\text { (SSK, Bağkur, Emekli sandığı) }\end{array}$ & illçe & & SGK \\
\hline
\end{tabular}

\section{Yöntem}

\section{1. Ayrıksı İlçelerin Tespiti}

İlk aşamada partilerin istatistiksel olarak düşük ve yüksek olarak kümelendikleri bölgeleri tespit edebilmek için ArcGIS programında yer alan mekânsal otokorelasyon yöntemlerinden Anselin Lokal Moran's I istatistiği (LISA) kullanılmıştır. Bilindiği üzere mekânsal otokorelasyon; global mekânsal otokorelasyon ve lokal mekânsal otokorelasyon olarak ikiye ayrılmaktadır. Global mekânsal otokorelasyonda yalnızca belli kümelenmenin olup olmadığı ve anlamlılık gösterip göstermediği tespit edilebilirken, lokal mekânsal otokorelasyonda kümelenmelerin nerede gerçekleştiği veyahut nerede anlamlı olup olmadığı gibi hususlar tespit edilebilmektedir. Dolayısıyla mekansal otokorelasyonu ölçen Anselin Lokal Moran's I istatistiği Tobler'in yukarıda da bahsedilen ‘Her şey her şeyle ilişkilidir, ancak yakın olan şeyler uzaktakilerden daha fazla ilişkilidir' şeklinde tanımladığı coğrafi mantık temeline oturur. Anselin tarafından geliştirilen bu analiz Moran's I istatistiğinin mekansallaşmış versiyonu olarak ifade edilebilir (Gündem, 2017; Işık ve Pınarcıoğlu, 2006; Kaya vd., 2015). Bir diğer ifadeyle bu analiz komşularıyla benzer değer gösteren bölgelerin istatistiksel açıdan anlamlı olarak kümelendiği bölgeleri ortaya çıkarmaktadır. Bu yönüyle Moran's I istatistiğinden ayrılırt. Mekânsal oto-korelasyon analizlerinde vurgulanması gereken husus analizlerin komşularla ilişki esasına dayanmasıdır (Aydın vd., 2018).

† Bilindiği üzere Moran I istatistiğiyle elde edilen katsayı mekanda birbirine benzeşen yerlerin anlamlı bir kümelenme gösterip göstermediğini ortaya koymaktadır. Ancak bu kümelenmelerin nerede olduğu sorusunu yanıtlayamamaktadır. Anselin tarafından geliştirilen ve Anselin Local Moran's I veya LISA olarak da bilinen teknik ise söz konusu benzerliklerin nerede gerçekleştiğine yanıt vermektedir (Gündem, 2017; 
Analiz neticesinde birbirine komşu olup ayn zamanda yüksek değerlerin görüldüğü bölgeler yüksek-yüksek küme ( $Y$-Y küme), birbirine komşu olup aynı zamanda düşük değerlerin görüldüğü bölgeler ise düşük-düşük (D-D küme) kümelenmelerin olduğu bölgeleri göstermektedir. Ortaya çıkan her iki kümelenme de komşularıyla benzer özellik gösteren bölgeleri ortaya koymaktadır. İstatistiksel olarak anlamsız olarak gösterilen bölgeler ise oy oranlarının yüksekliği veya düşüklüğüne göre mekânsal bir kümelenmenin olmadığını ifade etmektedir. Bir başka ifadeyle bu bölgeler komşularıyla ne yüksek oranlı ne de düşük oranlı olarak istatistiksel açıdan anlamlı bir birliktelik oluşturmamaktadır. Buraya kadar anlatılanlardan hareketle LISA'nın sınır komşuluğuna göre istatistiksel olarak anlamlı biçimde birbirine benzeyen ve birbirinden farklılaşan bölgeleri ortaya koyan bir analiz olduğu belirtilebilir ki bu durum coğrafyacıların komşuluk etkisi olarak adlandırdığı çerçeveye oturmaktadır. Öz itibariyle global Moran's I istatistiği genel olarak bir mekânsal otokorelasyonun olup olmadığını anlamaya imkan sağlarken, Anselin Lokal Moran's I istatistiği yakın ya da komşular arasındaki mekânsal ilişkinin anlamlılı̆ııı test eder (Gündem, 2017).

Yüksek ve düşük olarak anlamlı kümelenmelerin olduğu bölgeye komşu olmasına rağmen bu bölgelerden istatistiksel olarak farklılaşan bölgeler ise yüksek-düşük ayrıksı (Y-D ayrıksı) ve düşükyüksek ayrıksı (D-Y ayrıksı) ayrıksı bölgeler olarak gösterilmektedir ki bu bölgeler bu araştırmanın asıl odak noktasını oluşturmaktadır. Bu çerçevede ayrıksı olarak belirlenen ilçeler 1, ayrıksı olarak tespit edilen ilçelere komşu olup ondan farklı özellik gösteren komşuları ise 2 olarak kodlanmıştır. Oluşturulan bu iki grubun (yani ayrıksı olarak tespit edilen bölgeler ile ayrıksı bölgelerden anlamlı farklııık gösteren komşuları) birbirinden ayrışmasının ardında yatan nedenin demografik, kültürel ve ekonomik dinamiklere göre şekillenebileceği teorik arka plan kısmında anlatılanlardan hareketle a priori olarak bilinmektedir. Nitekim hem uluslararası (Clarke vd., 2004; Lipset, 1960; Mansley ve Demsar, 2015) hem de ulusal (Ataç ve Işık, 2013; Erder ve Tüzün, 2004; Gündem, 2017; Kardam ve Tüzün, 1998; Özözen-Kahraman, 2007; Turan, 2004; Tuysuz ve Gülmez, 2019) bağlamda yapılan çalışmalardan bazıları farklılaşmaların bahsedilen değişkenlere göre şekillenebileceğine dair bir bakış açısı sunmaktadır.

\section{1. Ayrıksı Illçelerin Komşularından Farklılaşmasını Sağlayan Dinamiklerin Tespiti}

Yukarıda bahsedilen yöntemle ayrıksı ilçeler tespit edildikten sonra ayrıksı ilçelerin kültürel, demografik ve ekonomik açıdan komşularıyla anlamlı bir farklılaşma gösterip göstermediğini anlamak için ise Mann-Whitney $U$ testi uygulanmıştır. Bilindiği üzere Mann-Whitney $U$ testi farklılaşmayı ortaya çıkaran $\mathrm{T}$ testinin parametrik olmayan alternatifidir. Bu analiz sayesinde yukarıda bahsedilen ayrıksı ilçelerin kendi komşusuyla demografik, kültürel ve ekonomik açıdan istatistiksel olarak anlamlı bir farklılaşma gösterip göstermediğini ortaya konulmuş olacaktır.

Işık ve Pınarcıoğlu, 2006). Illkinde anlamlı kümelenmeler haritalanamazken LISA testi aracılığıyla bu kümelenmelerin nerelerde gerçekleştiği haritalanabilmektedir. 


\section{Bulgular}

\section{1. Ayrıksı İlçelere iliş̧kin Bulgular}

2018 yllında gerçekleştirilen milletvekili genel seçimlerinde en çok oyu alan dört siyasi parti sırasıyla; Adalet ve Kalkınma Partisi (AKP), Cumhuriyet Halk Partisi (CHP), Halkların Demokratik Partisi (HDP) ve Milliyetçi Hareket Partisi (MHP) şeklindedir. Ancak bu partilerin Türkiye'nin her bölgesinde benzer bir oy potansiyeline sahip olmadığı bilinen bir gerçektir. Araştırmanın bulgularl; AKP, CHP ve MHP'nin hem yüksek hem de düşük oy aldığı ilçelerin yani birbirine benzer eğilimde olan komşu ilçelerin istatistiksel anlamlılık düzeyinde mekânsal olarak kümelendiğini, HDP'nin ise yalnızca yüksek oy aldığı ilçelerin istatistiksel olarak anlamlı bir kümelenmeye sahip olduğunu göstermektedir. Söz konusu bu kümelenmeler komşuluk etkisinin işlediğini göstermesi açısından önemlidir. Ancak sayıları az olsa da aşağıda bahsedilen ve bizim ayrıksı olarak tanımladığımız ilçeler ise komşuluk ilişkisinin homojenleştirici bir etki yaratmadığını göstermesi açısından çarpıcıdır.

Buradan hareketle komşularında oy oranı yüksek iken kendisi düşük oy veren (düşük-yüksek ayrıksı [D-Y ayrıksı]) ve komşularında oy oranı düşük iken kendisi yüksek oy veren (yüksek- düşük ayrıksı [Y-D ayrıksı]) ayrıksı ilçeler yalnızca AKP'de görülmektedir. Bir başka ifadeyle sınırlı da olsa komşuluk etkisinin işlemediği ilçeler yalnızca söz konusu partide gözlenmiştir. Bunlardan Posof (Ardahan), Altınözü (Hatay) ve Yayladağı (Hatay) gibi ilçeler AKP'ye yüksek oranda oy verirken, komşuları anlamlı biçimde AKP'ye düşük oranda oy veren ayrıksı ilçeler olarak tespit edilmiştir (Tablo 2, Şekil 1).

Komşusundaki oy oranı anlamlı bir biçimde yüksek iken CHP'nin düşük oy oranına sahip olduğu ayrıksı olanlar ise Arnavutköy (İstanbul), Sultanbeyli (İstanbul) ve Altınözü (Hatay) ilçeleridir (Tablo 2, Şekil 1). MHP'de ise ayrıksı ilçeler Doğubayazıt (Ağrı) ve İslahiye (Gaziantep) ilçelerinde görülmektedir. Bir başka ifadeyle Doğubayazıt ve i̇slahiye'nin komşuları anlamlı olarak MHP'nin yüksek oranda kümelendiği bölgeler iken söz konusu ilçeler anlamlı olarak bu ilçelerden ayrışmaktadır (Tablo 2, Şekil 2). HDP'de ise istatistiksel olarak ayrıksı herhangi bir ilçe gözlenmemektedir. Bir diğer ifadeyle kendisi yüksek oranda oy verip komşusu düşük oranda oy veren veya tam tersi bir durum HDP'de gözlenmemektedir (Tablo 2, Şekil 2). Dolayısıyla HDP'ye oy veren ilçelerin komşusundan farklı düşünmemesi söz konusu siyasi partinin homojen bir mekansal örüntü oluşturduğunu ve komşuluk etkisinin yüksek düzeyde olduğunu ortaya koymaktadır. 
Eskişehir Osmangazi Üniversitesi Sosyal Bilimler Dergisi

Tablo 2: Tespit Edilen Ayrıksı İlçeler ve Komşuları

\begin{tabular}{|c|c|c|c|}
\hline & $A K P$ & $\mathrm{CHP}$ & MHP \\
\hline $\begin{array}{l}\text { Sütundaki partiye göre } \\
\text { komşusundan anlamlı olarak } \\
\text { farklılaşan ayrıksı ilçe }\end{array}$ & İmranlı & Altınözü & Doğubayazıt \\
\hline Ayrıksı ilçenin komşuları & $\begin{array}{l}\text { Akıncılar } \\
\text { Refahiye } \\
\text { Suşehri }\end{array}$ & Defne & $\begin{array}{c}\text { Aralık } \\
\text { Iğdır merkez } \\
\text { Karakoyunlu }\end{array}$ \\
\hline $\begin{array}{l}\text { Sütundaki partiye göre } \\
\text { komşusundan anlamlı olarak } \\
\text { farklılaşan ayrıksı ilçe }\end{array}$ & Altınözü & Arnavutköy & İslahiye \\
\hline Ayrıksı ilçenin komşuları & Defne & $\begin{array}{l}\text { Büyükçekmece } \\
\text { Çatalca } \\
\text { Eyüpsultan }\end{array}$ & $\begin{array}{c}\text { Bahçe } \\
\text { Dörtyol } \\
\text { Hasanbeyli } \\
\text { Hassa } \\
\text { Kilis merkez, Musabeyli } \\
\text { Nurdağı } \\
\text { Osmaniye merkez } \\
\end{array}$ \\
\hline $\begin{array}{l}\text { Sütundaki partiye göre } \\
\text { komşusundan anlamlı olarak } \\
\text { farklılaşan ayrıksı ilçe }\end{array}$ & Posof & Sultanbeyli & \\
\hline Ayrıksı ilçenin komşuları & Damal, Hanak & Kartal & \\
\hline $\begin{array}{l}\text { Sütundaki partiye göre } \\
\text { komşusundan anlamlı olarak } \\
\text { farklılaşan ayrıksı ilçe }\end{array}$ & Yayladağı & & \\
\hline Ayrıksı ilçenin komşuları & $\begin{array}{c}\text { Defne } \\
\text { Samandağ }\end{array}$ & & \\
\hline
\end{tabular}


Şekil 1: AKP ve CHP’nin Oy Oranlarına Göre Kümelenen ve Ayrıksılaşan illçeler.

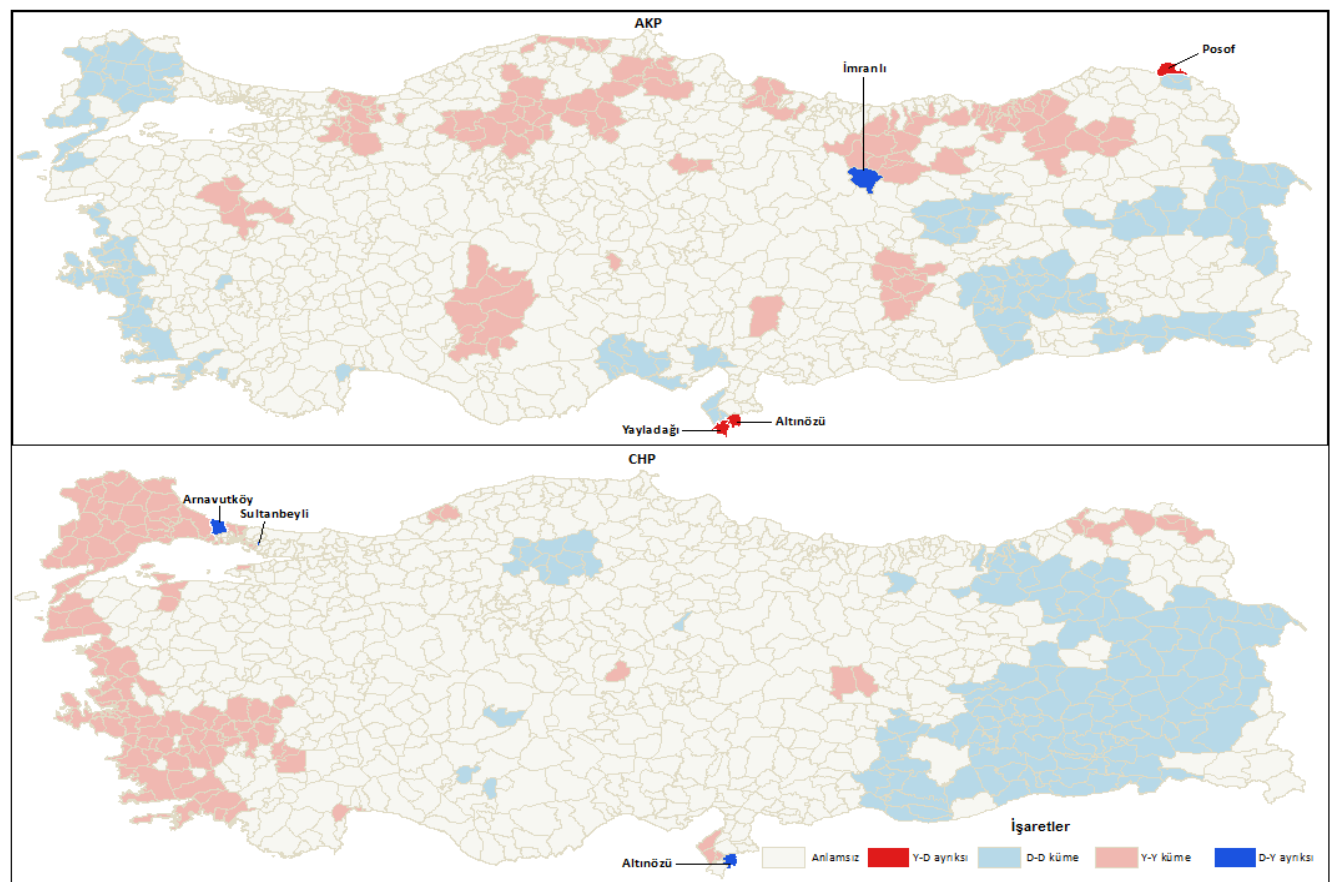


Şekil 2: MHP ve HDP'nin Oy Oranlarına Göre Kümelenen ve Ayrıksılaşan İlçeler

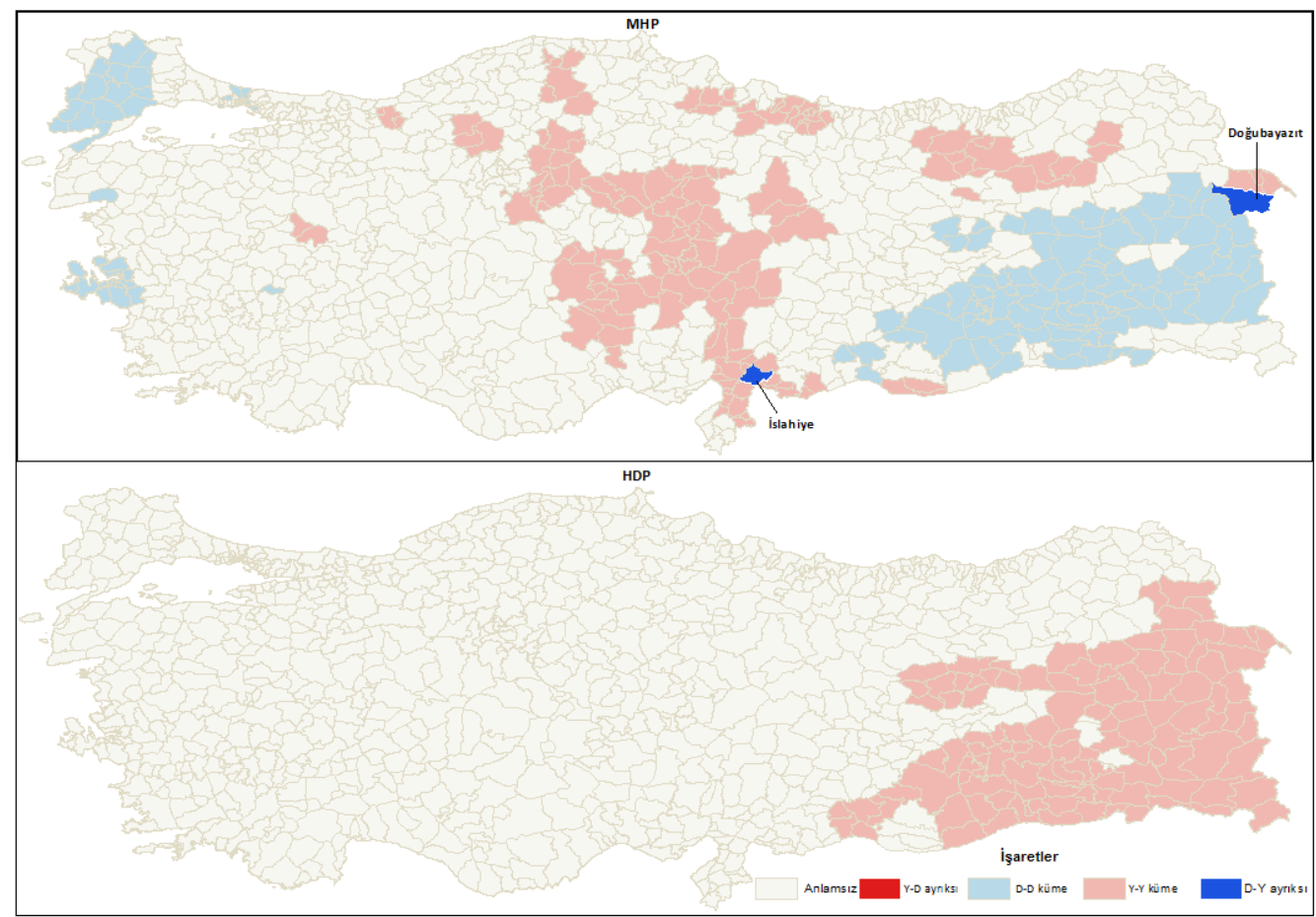

\section{1. Ayrıksı İlçelerin Farklılaşmasını Sağlayan Faktörlere iliş̧kin Bulgular}

Ayrıksı olarak belirlenen ilçeleri komşularından ayrıştıran dinamiklerin belli bir düzene ya da düzensizliğe göre şekillenip şekillenmediğini tespit etmek için uygulanan Mann-Whitney $U$ testi sonuçları, ayrıksı ilçelerin bazı değişkenler açısından komşularından farklılaştığını göstermektedir. Analize alınan demografik (yaş grupları), ekonomik (istihdam) ve kültürel (eğitim durumu) değişkenlerden yalnızca kültürel değişken olarak tanımlanan eğitim düzeyinde farklılaşmanın gerçekleştiği görülmektedir. Yani ayrıksı ilçeler; ilköğretim, ortaöğretim ve üniversite mezunları açısından komşularından anlamlı şekilde bir farklılaşmaktadır. Elde edilen Mann-Whitney $U$ testi değerleri ilköğretim mezunu nüfus için $(U=59,000, p=0,048)$, ortaöğretim mezunu nüfus için $(U=52,000, p=0,024)$ ve üniversite mezunu nüfus için ise $(U=49,000, p=0,017)$ şeklindedir (Tablo 3$)$.

Yukarıda bahsedilen demografik ve ekonomik değişkenler açısından ise ayrıksı ilçelerle komşuları arasında anlamlı bir farklılaşma gözlenmemiştir. 
Tablo 3: Mann-Whitney U Testi Sonuçları.

\begin{tabular}{|c|c|c|c|c|c|c|c|c|c|}
\hline \multicolumn{10}{|c|}{ Mann-Whitney U Test Statistics ${ }^{a}$} \\
\hline & $\begin{array}{l}\text { Sigortalı } \\
\text { nüfusun ilçe } \\
\text { nüfusuna } \\
\text { oranu }\end{array}$ & \multicolumn{4}{|c|}{$\begin{array}{c}\text { Seçim çağındaki nüfusun yaş } \\
\text { gruplarına } \\
\text { Oranı }\end{array}$} & \multicolumn{4}{|c|}{$\begin{array}{c}\text { Seçim çağındaki nüfusun eğitim durumuna } \\
\text { göre oranı }\end{array}$} \\
\hline & $\begin{array}{l}\text { Sigortalı } \\
\text { oranı }\end{array}$ & $20-34$ & $35-49$ & $50-64$ & $\begin{array}{l}65 \text { ve } \\
\text { üzeri }\end{array}$ & $\begin{array}{c}\text { Okul } \\
\text { bitirmeyen } \\
\text { ve okuma } \\
\text { yazma } \\
\text { bilmeyen }\end{array}$ & Illköğretim & $\begin{array}{l}\text { Ortaöğreti } \\
\mathrm{m}\end{array}$ & $\begin{array}{l}\text { Üniversit } \\
\text { e }\end{array}$ \\
\hline $\begin{array}{l}\text { Mann- } \\
\text { Whitney } \\
\text { U }\end{array}$ & 98,000 & $\begin{array}{c}64,00 \\
0\end{array}$ & 83,000 & 68,000 & 108,000 & 77,000 & 59,000 & 52,000 & 49,000 \\
\hline $\begin{array}{l}\text { Wilcoxon } \\
\text { W }\end{array}$ & 143,000 & $\begin{array}{c}364,0 \\
00\end{array}$ & 128,000 & 113,000 & 408,000 & 377,000 & 359,000 & 97,000 & 94,000 \\
\hline $\bar{Z}$ &,- 404 & $-1,779$ & $-1,011$ & $-1,618$ & 0,000 & $-1,254$ & $-1,982$ & $-2,265$ & $-2,386$ \\
\hline $\begin{array}{l}\text { Asymp. } \\
\text { Sig. (2- } \\
\text { tailed) }\end{array}$ & 686 & ,075 & 312 & 106 & 1,000 & 210 & ,048* & ,024* & ,017* \\
\hline $\begin{array}{l}\text { Exact Sig. } \\
{[2 *(1-} \\
\text { tailed } \\
\text { Sig. })]\end{array}$ &, $706^{b}$ & $079^{b}$ & $328^{b}$ &, $111^{b}$ & $1,000^{b}$ &, $222^{b}$ & $049^{b}$ & $023^{b}$ & $016^{b}$ \\
\hline $\begin{array}{l}\text { a. } \\
\text { b. } 1\end{array}$ & $\begin{array}{l}\text { rouping Vari } \\
\text { ot corrected }\end{array}$ & $\begin{array}{l}\text { able: } A) \\
\text { for ties }\end{array}$ & yrıksı il & r ve & şuları & & & & \\
\hline
\end{tabular}

\section{Tartışma}

Bu çalışmanın asıl odağı olan ayrıksı ilçelere geçmeden önce komşuluk ilişkisine göre birbiriyle benzeşen ilçelere bakıldığında bunun üretilen haritada oldukça fazla bir alan kapladığı görülmektedir. Ayrıksı ilçelerin ise çok daha sınırlı sayıda olduğu görülmektedir. Ayrıksılaşan ilçelerden yalnızca Hatay'ın Yayladağı ve Altınözü ilçeleri ayrıksı birliktelik oluşturan ilçeler olarak belirginleşmiştir.

Çalışmanın asıl odağı olan ilçelerin kimi yerlerde Özözen-Kahraman ve Gültay’ın (2019) tespit ettiği sıradışı ilçelerden farklılaştığı kimi yerlerde ise benzerlik gösterdiği görülmektedir. Kuşkusuz bu komşuluk ilişkisini esas alarak ayrıksı ilçelerin tespitine yönelik yöntemsel bir farklılaşmadan kaynaklanmaktadır. Özözen-Kahraman ve Gültay (2019) araştırmasına benzer şekilde bu araştırmada da ayrıksı olarak tespit edilen ilçelerin kimilerinin benzeşmesi; benzeşen ilçelerin siyasal tercihlerinde kararlı bir şekilde hem komşularından hem de Türkiye genelinden farklı bir tutum 
sergilediklerini göstermektedir. Üst üste farklı seçim dönemlerinde farklılaşan ilçelerin siyasi tercihlerindeki kemikleşme belli bir siyasal ideolojinin mekânsallaşması olarak tanımlanabilir.

Bu noktada dikkat çeken ilçeler şöyledir: Sınır komşuluğu olup ancak istatistiksel anlamlılık açısından birbirinden ayrışan Çatalca, Damal, Defne, Doğubayazıt, Dörtyol Hanak, Hasanbeyli, Iğdır merkez, İmranlı, Karakoyunlu, Osmaniye merkez ve Samandağ gibi ilçelerin siyasi eğilimleri ÖzözenKahraman ve Gültay (2019) tespit ettiği sıradışı ilçelerle aynıdır. Bu durum farklı yöntemlerle yapılmış olsa bile söz konusu ilçelerin siyasal eğilimlerinin tekrar eden şekilde farklılaşan bir nitelik kazandığını göstermesi bakımından önemlidir. Bizim araştırmamızda komşularına göre anlamlı olarak farklılaşan Akıncılar, Refahiye Suşehri, Sultanbeyli, Kartal, Büyükçekmece, Arnavutköy, Eyüpsultan, Musabeyli, Hassa, Kilis merkez, Nurdağı, İslahiye, Aralık, Yayladağı gibi ilçeler ise Özözen-Kahraman ve Gültay'ın (2019) çalışmalarında tespit edilenlerden farklıık göstermektedir. Bir kez daha vurgulamak gerekir ki bu durum mevcut araştırmadaki ayrıksılı̆ıın komşuluk ilişkisine göre tespit edilmesinden kaynaklanabileceği gibi seçim yılının farklılaşmasından da kaynaklanabilir.

Ayrıksılaşan ilçelerin komşularından farklılaşma nedenini anlamaya yönelik olan yapılan analiz sonuçları mekânsal yakınlığın her durumda homojenlik yaratmayacağını göstermektedir. Nitekim ayrıksılaşan ilçelerin eğitim faktörü açısından farklılaşması seçmen tercihlerinin kimi durumlarda komşuluk ilişkisine göre şekillenmediğini göstermesi bakımından önemlidir. Farklılaşma testinde ön plana çıkan eğitim faktörü, seçimlerde en fazla dikkate alınan sosyo-demografik özelliklerden biridir. Bu açıdan, yapılan çalışmalarda olduğu gibi bizim çalışmamızda da eğitim ön plana çıkmıştır. Örneğin, Balcı ve diğerleri (2019) 16 Nisan 2017 Anayasa Değişikliği Referandumu'nda seçmenlerin eğitim durumlarını incelemiş ve eğitim düzeyi arttıkça siyasal davranışlarında bir değişiklik olduğunu bulmuştur. Balcı ve diğerleri (2019) ise okur yazarlık oranı arttıkça seçmenlerin yazılı ve görsel medyadan etkilenmesinin azaldığını ortaya koymuştur. Diğer yandan, seçmenlerin parti tercihi ve kararııı̆̆ ile ilgili yapılan çalışmada da Çavuşoğlu ve Pekkaya (2016) parti adayının seçiminde seçmenin okur yazarlık düzeyinin anlamlı bir rol oynadığını; ayrıca adayın eğitim düzeyinin de seçmenin tercihinde önemli bir belirleyici olduğunu göstermektedir. Öte yandan eğitimin, siyasal rejim değişikliklerinde dahi ittirici bir güç olabileceği belirtilmektedir (Eyidiker, 2019).

\section{Sonuç}

Eski Atina şehir devletlerinden itibaren uygulanagelen seçimler; siyaset bilimi, coğrafya, sosyoloji ve iktisat gibi sayıları daha da artırılabilecek birçok disiplinin ilgi alanına giren bir çerçeveye sahiptir. Bu araştırmada ele alındığı üzere siyaset biliminin faaliyet alanına giren seçimlerin mekân tarafından şekillendirici rolüne odaklanılış̧ır ki bu da coğrafya ve siyaset biliminin etkileşimini ortaya koymaktadır. Bu araştırma, komşuluk etkisine göre partilerin kümelendikleri bölgeleri Anselin Lokal Moran's I istatistiği kullanarak tespit etmenin yanı sıra yine aynı istatistik yöntemle komşuluk etkisinin aksine işlediği bölgeleri de tespit eden bir yaklaşıma sahiptir. Çalışma, özellikle Tobler'in ‘her şey birbiriyle ilişki içindedir, ama mekânsal olarak birbirine yakın olan olay ve süreçler birbirini daha çok etkiler' şeklindeki yasasının işlemediği bölgelere odaklanması açısından literatüre orijinal katkı sunmayı hedeflemektedir. Kuşkusuz buradan komşuluk etkisinin olmadığı gibi bir anlam çıkarılamaz 
ancak sayıları az olsa da ayrıksı olarak tanımladığımı ilçelerde komşuluğun her durumda homojenleştirici bir etki yaratmadığını belirtmek gerekir. Bu çerçevede sınır komşusu olmasına rağmen komşusundan istatistiksel olarak anlamlı bir biçimde farklılaşan ilçelerin komşularından farklılaşmasını sağlayan dinamikler kültürel, demografik ve ekonomik değişkenler üzerinden tespit edilmeye çalışılmışır. Mann-Whitney $U$ testi uygulanarak elde edilen sonuçlar; ayrıksı olarak tespit edilen ilçelerin eğitim durumu açısından anlamlı biçimde komşularından farklılaştığını ortaya koymaktadır. Kuşkusuz farklılaşmayı yarattığı tespit edilen dinamikler ancak verinin ilçe bazında temin edilebilirliği ölçüsünde gerçekleştirilebilmiştir. Bu durum ilçe ölçeğinde yapılan çalışmalar için en büyük sınırlıı̆ı oluşturmaktadır. Dolayısıyla ilçe ölçeğinde daha geniş bir veri setinin üretilmesi bu ve benzeri çalışmalar için daha geniş bir değerlendirme yapmaya imkân tanıyacaktır. Ayrıca gelecek çalışmalarda yalnızca ayrıksı ilçelere odaklanılarak yapılacak nitel araştırmalar ayrıksılaşmayı yaratan dinamikleri anlamaya yönelik bulguların zenginleşmesini sağlayacaktır.

\section{Araştırma ve Yayın Etiği Beyanı}

Bütün yazarlar araştırmanın oluşum aşamasında rol almış, tamamını okumuş, onaylamış ve makalenin orijinal olduğunu beyan etmiştir. Araştırmada anket, mülakat, gözlem, deney vb. gibi etik kurul izni gerektiren bir durum yoktur.

\section{Yazarların Makaleye Katkı Oranları}

Araştırmaya ilk yazar \%50, ikinci yazar \%35, üçüncü yazar ise \%15 oranında katkı sağlamıştır.

\section{Çıkar Beyanı}

Yazarların herhangi bir çıkar çatışması yoktur.

\section{Kaynaklar}

Almond, G. A. ve Verba, S. (2015), The Civic Culture: Political Attitudes and Democracy in Five Nations, Princeton: Princeton University Press.

Anderson, M. R. (2009), Beyond membership: A sense of community and political behavior, Political Behavior, 31(4), 603-627.

Ataç, E. ve Işık, O. (2013), 'Büyük dönüşüm' öncesi Türkiye kentlerinde ayrışma ve siyaset, Toplum ve Bilim, 127, 229-241.

Aydın, O., Aslantaş-Bostan, P. ve Özgür, E. M. (2018), Mekânsal veri analizi teknikleriyle Türkiye'de toplam doğurganlık hızının dağılımı ve modellenmesi, Coğrafya Dergisi, 37, 27-45.

Balcı, Ş., Tanacı, F., Dağlı, A. N. ve Bayrak, E. (2019), 16 Nisan 2017 Anayasa Değişikliği Referandumu sürecinde siyasal bilgilenme ve medya: Eğitim düzeyine göre bir karşılaştırma, Erciyes iletişim Dergisi, 6(1), 1-16.

Bergmann, M., Konzelmann, L. ve Rattinger, H. (2012), Is Germany on the path to a "pensioner democracy"? An empirical investigation of age-specific differences in political attitudes and 
their relevance for electoral behavior based on a recent survey, Politische Vierteljahresschrift, 53(3), 371-393.

Bølstad, J. ve Dinas, E. (2017), A categorization theory of spatial voting: How the center divides the political space, British Journal of Political Science, 47(4), 829-850.

Clarke, H. D., Sanders, D., Stewart, M. C. ve Whiteley, P. (2004), Political Choice in Britain, Oxford: Oxford University Press.

Cottam, M. L., Dietz, B., Mastors, E. ve Preston, T. (2004), Introduction to Political Psychology, New Jersey: Lawrence Erlbaum Associates Inc.

Cox, K. R. (1969a), The spatial structuring of information flows and partisan attitudes, Quantitative Ecological Analysis in the Social Sciences, 157-186.

Cox, K. R. (1969b), The voting decision in a spatial context, Progress in Geography, 1, 81-117.

Cox, K. R. (1969c), Voting in the London suburbs: a factor analysis and a causal model, Quantitative Ecological Analysis in the Social Sciences, 343-370.

Çavuşoğlu, H. ve Pekkaya, M. (2016), Yerel seçimlerde genç seçmenlerin siyasal davranışlarına ilişkin bir inceleme: Bülent Ecevit Üniversitesi örneği, Uluslararası Yönetim iktisat ve Işsletme Dergisi, 12(29), 17-40.

Del Monte, A., Moccia, S., Pennacchio, L. (2019), Turnout and voting behaviour in constitutional referendums: A regional analysis of the Italian case, Regional Studies Regional Science, 6(1), 557-573.

Deutschmann, E., Delhey, J., Verbalyte, M. ve Aplowski, A. (2018), The power of contact: Europe as a network of transnational attachment, European Journal of Political Research, 57(4), 963-988.

Domosh, M., Neumann, R. P., Price, P. L., Jordan-Bychkov, T. G. (2010), The Human Mosaic: A Cultural Approach to Human Geography (12th ed.), New York: W. H. Freeman and Company.

Erder, N. ve Tüzün, S. (2004), Türkiye'de Seçmen Eğilimlerinde Yeni Açılımlar (1994-2004), İstanbul: Tüses Yayınları.

Eyidiker, U. (2019), Siyasal davranış: Siyasal katılıma giden yol, Journal of Social, Humanities and Administrative Sciences, 5(18), 704-719.

Festınger, L., Schachter, S. ve Back, K. (1963), Social Pressures in Informal Groups: A Study of Human Factors in Housing, Standford: Stanford University Press.

Flint, C. (1996), Whither the Individual, Whither the Context?, Political Geography, 15(2), 147-151.

Gündem, F. (2017), Türkiye'de Seçmen Davranışlarının Belirleyenleri: Mekansal Ekonometrik Bir Yaklaşım, K. Temurçin, M. A. Dulupçu İçinde, Türkiye'de Mekansal ve Bölgesel Dönüşümler (s. 15-30), Isparta: Süleyman Demirel Üniversitesi Yayınları. 
Işık, O. ve Pınarcıoğlu, M. (2006), Bölgesel siyasi tercihler ve AKP, Toplum ve Bilim, 107, 66-86.

Johnson, M., Shively, W. P. ve Stein, R. M. (2002), Contextual data and the study of elections and voting behavior: Connecting individuals to environments, Electoral Studies, 21(2), 219-233.

Johnston, R., Jones, K., Sarker, R., Propper, C., Burgess, S. ve Bolster, A. (2004), Party support and the neighbourhood effect: Spatial polarisation of the British electorate, 1991-2001, Political Geography, 23(4), 367-402.

Johnston, R. J. (1986), The neighbourhood effect revisited: Spatial science or political regionalism?, Environment and Planning D: Society and Space, 4(1), 41-55.

Kardam, A., Tüzün, S. (1998), Türkiye'de Siyasi Kutuplaşmalar ve Seçmen Davranışları, Ankara: Veri Araştırma.

Kaya, Ö., Toroğlu, E. ve Adıgüzel, F. (2015), 2011 Genel seçimlerinde partilerin aldığı oy oranlarının ilçeler ölçeğinde mekânsal analizi, Coğrafya Dergisi, (31), 1-13.

Kinsella, C., Mctague, C. ve Raleigh, K. N. (2015), Unmasking geographic polarization and clustering: A micro-scalar analysis of partisan voting behavior, Applied Geography, 62, 404-419.

Lipset, S. M. (1960), Political Man: The Social Bases of Politics, Garden City, NY: Double Day and Company Inc.

Mansley, E. ve Demsar, U. (2015), Space matters: Geographic variability of electoral turnout determinants in the 2012 London mayoral election, Electoral Studies, 40, 322-334.

Mikesova, R. (2019), Influence of the Local context on voting behavior in Czechia, Geografie, 124(4), 411-432.

Ochoa-Espejo, P. (2016), Taking place seriously: Territorial presence and the rights of immigrants, Journal of Political Philosophy, 24(1), 67-87.

Özözen-Kahraman, S., Gültay, B. (2019), Türkiye'de parti tercihlerinde sıradışı içelerin belirlenmesi (2007-2015), Amme Idaresi Dergisi, 52(3), 95-122.

Özözen-Kahraman, S. (2007), Seçimlerin Mekânsal Analizi, Ankara: Gazi Kitapevi.

Pattie, C. ve Johnston, R. (1999), Context, conversation and conviction: Social networks and voting at the 1992 British General Election, Political Studies, 47(5), 877-889.

Pattie, C. ve Johnston, R. (2000), 'People who talk together vote together': An exploration of contextual effects in Great Britain, Annals of the Association of American Geographers, 90(1), 41-66.

Turan, A. E. (2004), Türkiye'de Seçmen Davranışı: Önceki Kırılmalar ve 2002 Seçimi, İstanbul: İstanbul Bilgi Üniversitesi Yayınları. 
Tuysuz, S. ve Gülmez, R. (2019), Instrumentalisation of gerrymandering in recentralization in Turkey: The case of Ankara, International Journal of Geography and Geography Education, (40), 139150.

Walks, R. A. (2005), City-suburban electoral polarization in Great Britain, 1950-2001, Transactions of the Institute of British Geographers, 30(4), 500-517.

Walks, R. A. (2006), The causes of city-suburban political polarization? A Canadian case study, Annals of the Association of American Geographers, 96(2), 390-414. 